\title{
MAGATARTÁSI NEHÉZSÉGEK KEZELÉSE A XX. SZÁZAD ELSŐ FELÉNEK MAGYAR NÉPISKOLÁIBAN
}

\section{Szerző:}

Dr. Pornói Imre (PhD.)

Debreceni Egyetem (Magyarosrszág)

Első szerző e-mail címe:

pornoi.imre@ped.unideb.hu
Lektorok:

Vargáné Dr. Nagy Anikó (PhD.)

Debreceni Egyetem (Magyarosrszág)

Dr. Fenyő Imre (PhD.)

Debreceni Egyetem (Magyarosrszág)

Pornói Imre (2019): Magatartási nehézségek kezelése a XX. század első felének magyar népiskoláiban. Különleges Bánásmód, 5. (2). 41-54. DOI 10.18458/KB.2019.2.41

\begin{abstract}
Absztrakt
A 19. század vége - és a 20. század első fele a polgári nemzetállamokban az oktatás kiszélesítésének, az analfabétizmus felszámolásának korszaka volt. A tankötelezettségi törvények az alsóbb társadalmi rétegek számára is lehetőséget biztosítottak szociális helyzetük javításában is szerepet játszó iskolai végzettség megszerzésére. Az iskola, mint szocializációs terep, értéknormáiban, magatartási és ismereti elvárásaiban a mindenkori rendszer politikai és társadalmi stabilitását szolgálta. Mivel a társadalom különböző csoportjaiban ezek, az iskola által elvártaktól sok esetben eltértek, a tanulók magatartásában jelentkezve állandó fegyelmezési problémák meglétét okozták, mellyel visszatérően foglalkoztak a pedagógiai, és pszichológiai sajtóban és kiadványokban.

Magán a fegyelmezésen általában a külső rend megteremtését értették, mely során fő szerepet játszott a pedagógus példaadása a rendre, pontosságra szoktatásban. Tiszteletet ébresztőnek tartották a pedagógus jóakaratát, igazságosságát, részrehajlástól és személyeskedéstől mentességét a jutalmazás és a büntetés során. A büntetési formák iskolafokozatonként eltérőek voltak. Az elemi népiskolában a négyszemközt való megintés, pirongatás, padból való kiállítás eredménytelensége esetén a tanulót felügyelet mellett bennmarasztalták az iskolában. A szülő értesítése, s a tanuló tantestület előtt való megintése előzte meg a gondnokságnak történő bejelentést. Utóbbi intézkedésével fejeződött be a népiskola büntetések sora. A polgári és a középiskolákban az osztályfőnöki és az igazgatói megrovást a tanári testület előtt való megrovás, az intézetből való csendes, illetve az ország valamennyi polgári, illetve középiskolájából való eltávolítás, kizárás követte. Utóbbihoz az illetékes felsőbb hatóságok jóváhagyására volt szükség. Ezen iskolákban a testi fenyítésen túl tiltott volt a bezárás, különböző büntetési feladatok adása, a kitérdeltetés, az óráról való kiküldés, s a táplálékmegvonás is.
\end{abstract}

Kulcsszavak: neveléstörténet, módszertan, nevelés, fegyelmezés, testi fenyítés

Diszciplina: pedagógia

\section{Abstract}

MANAGING BEHAVIORAL DIFFICULTIES OF THE FOLK SCHOOLS IN THE FIRST HALF OF THE 20TH CENTURY IN HUNGARY

The end of the 19th century and the first half of the 20th century was a period of widening education and eradicating illiteracy in civil nation states. The compulsory education laws also provided opportunities for the lower social classes to obtain a school qualification that also contributed to improving their social situation. The school as a socialization terrain, in its standards, behavioral and knowledge expectations, 
served the political and social stability of the current system. Because in many different groups of society they differ in many ways from the expectations of the school, in the behavior of the students, they caused the existence of permanent discipline problems, which were repeatedly dealt with in the pedagogical and psychological press and publications.

Discipline generally meant creating an external order, in which the main role was the example of the teacher. During the reward and punishment, the goodwill and justice of the teacher were considered important. The forms of punishment were different at school level. At elementary school, pupils were first given oral warnings. Then the parents were informed, then the teaching staff and the guardians took action. In secondary schools, punishment ranged from verbal reprimand to exclusion from school. In high schools, physical punishments were forbidden.

Keywords: history of education, methodology, education, disciplining, corporal punishment Disciplines: pedagogy

A 19. század vége - és a 20. század első fele a polgári nemzetállamokban az oktatás kiszélesítésének, az analfabétizmus felszámolásának korszaka volt. A tankötelezettségi törvények az alsóbb társadalmi rétegek számára is lehetôséget biztosítottak szociális helyzetük javításában is szerepet játszó iskolai végzettség megszerzésére. Az iskola, mint szocializációs terep, értéknormáiban, magatartási és ismereti elvárásaiban a mindenkori rendszer politikai és társadalmi stabilitását szolgálta. Mivel a társadalom különböző csoportjaiban ezek, az iskola által elvártaktól sok esetben eltértek, a tanulók magatartásában jelentkezve állandó fegyelmezési problémák meglétét okozták, mellyel visszatérōen foglalkoztak a pedagógiai, és pszichológiai sajtóban és kiadványokban.

\section{Fegyelem, fegyelmezés}

Fegyelem, azaz disciplina alatt többek között az erkölcsi és testületi törvények és szabályok szokásszerú és ellenőrzött megtartását (KL. 1931. 82.), egy adott szervezet céljainak vagy feladatainak eléréséhez szükséges, s tagjainak sikeres együttmúködését biztosító rendet (RNL, VII.1913. 241.) értették.

Az 1936-ban kiadott Pedagógiai Lexikon szerzői a fegyelem céljaként az iskolai munka zökkenőmentes, nyugodt menetének biztosítását jelölték meg, melyhez szükségesnek látták a tanulók órát nem zavaró magatartását. A fegyelem kialakításának egyik legnagyobb problémáját a közösség és az egyén akaratérvényesítésének összehangolásban látták. Ugyanis amíg a közösség parancsokat, tilalmakat fogalmaz meg, addig az egyén szabadságra és önállóságra törekszik. E kettőnek az egyensúlyától függött a kialakítandó fegyelem eredményessége és tartóssága. Ebben a pedagógiai folyamatban a külső, 'rákényszerített' fegyelmet a belső 'önként vállalt' fegyelem, az önfegyelem váltja fel, s eredményességét bizonyítja, ha a tanuló akkor is az erkölcsi szabályoknak megfelelóen viselkedik, ha már nem áll az iskola, vagy a család közvetlen ellenőrzése alatt (pl. I. rész, 1936. 559.).

A fegyelem kialakítása során eszközök széles körét alkalmazták, melyek sorába tartozónak tartották a készségek tudatos és következetes fejlesztését, a szoktatást, a belső alakulást irányítóját (KL. 1931. 82.) A nevelés erkölcsi rendeltetésű részeként szereplő fegyelmezés feladatának a jellem alakítását nevezték, melynek külső jele volt a rend, és engedelmesség. (RNL, VII. 1913. 241.)

Magán a fegyelmezésen tehát általában a külső rend megteremtését értették, mely során fó szerepet játszott a pedagógus példaadása a rendre, pontosságra szoktatásban. Tiszteletet ébresztőnek nevezték a pedagógus jóakaratát, igazságosságát és részrehajlástól és személyeskedéstől mentességét a jutalmazás és büntetés, a felügyelet és a foglalkoztatás során. A büntetés fenyegetőzés mentességét, higgadt megfontoltságát, és a tanulók egyéniségéhez való alkalmazkodását hangsúlyozták, mivel a testi fenyítést a különböző iskolafajták rendtartásai tiltották. A büntetési formák is- 
kolafokozatonként eltérőek voltak. Így az elemi népiskolában a négyszemközt való megintést, pirongatást a padból való térdeltetés nélküli kiállítás követte. Ezek eredménytelensége esetén a tanulót felügyelet mellett bennmarasztalták az iskolában. A szülő értesítése, s a tanuló tantestület előtt való megintése előzte meg a gondnokságnak történő bejelentést. Utóbbi intézkedésével fejeződött be a népiskola büntetések sora.

A polgári és a középiskolákban az osztályfőnöki és az igazgatói megrovás lehetett négyszemközti, osztály, illetve szülők előtti. Ezt a tanári testület előtt való megrovás, esetleg az intézetből való csendes eltávolítás követte. Erkölcsi szempontból súlyos vétség büntetése volt a tanulónak az intézményből, illetve az ország valamennyi polgári, illetve középiskolájából való kizárása. Utóbbihoz az illetékes felsőbb hatóságok jóváhagyására volt szükség. Ezen iskolákban a testi fenyítésen túl tiltott volt a bezárás, különböző büntetési feladatok adása, a kitérdeltetés, az óráról való kiküldés, s a táplálékmegvonás is (pl. I. rész, 1936. 561.)

\section{Állami beavatkozás}

Az 1909-ben kiadott népiskolai utasítás 131. §-a foglalkozott az iskolai fegyelemmel és eszközeivel. Kiemelt fontosságát az adta, hogy ezt tekintették a sikeres oktatás és erkölcsi nevelés alapfeltételeinek. Éppen ezért szükségesnek látták a tanító példaadását saját környezetében, $s$ mind a szülőkkel, mind a tanulókkal való bizalmi kapcsolatának kialakítását. Utóbbi kialakításában a jutalmazás és büntetés méltányosságára, a kivételezés elkerülésére, a követelmények betartatására, s a tömeges büntetés elkerülésére hívták fel a figyelmet (1909. évi 53.000. VKM.sz. 1632.). Mindehhez fontosnak tartották a megfelelő iskolába járás biztosítása mellett az iskolák fegyelmi szabályainak és a tanulók kötelességeit tartalmazó házirendek kidolgozását és alkalmazását. A tanulók fegyelmezetlenségeivel szembeni iskolai fellépésnek figyelembe kellet vennie a tanulók egyéniségét. Minden esetben elutasította a rendelet a durva büntetést. Ezzel szemben a szelídséget, a komolyságot, a higgadtságot hangsúlyozták. A fegyelmezés legbiztosabb és leghelyesebb eszközeit a megfelelő tanítási módszerek alkalmazásában, s a tanítók lélektani ismereteiben látták. Ezzel kapcsolatban megkülönböztetően fontosnak vélték a tanulás elhanyagolásából, a vérmérsékletből és az erkölcstelen hajlamokból következő magatartási problémák megkülönböztetését, kiemelve a tanítók megelőző tevékenységét. Viszont csak a számukra megoldhatatlan esetekben kellett a gondnokság útján a szülőkhöz fordulni. (1909. évi 53.000. VKM.sz. 1633.) A büntetési tételek 8 (a-h) pontjából 5 a tanító személyes, 2 a tanítótestület, illetve a gondnokság beavatkozása volt, s 1 vonatkozott a szülők szó-vagy írásbeli értesítésére. (1909. évi 53.000. VKM.sz. 1634.)

A 8 osztályos népiskola számára 1942-ben kiadott rendtartás a tanítótól a fegyelmezésben önuralmat, türelmet, szeretetet, következetességet követelt, s a büntetés megtorló jellegével szemben a javítás és a megelőzés fontosságát hangsúlyozta. A büntetések során a gyermek megalázásnak elkerülésére hívta fel a figyelmet, rámutatva arra, hogy a tanító fegyelmileg és büntetőjogilag is felelőssé tehető a tanulónak okozott testi, illetve egészségsértés miatt. Fontosnak tartotta a gondviselő értesítését és bevonását a súlyosabb fegyelmi vétségek esetén. Ugyanakkor a tanuló fejlődésére káros, őt veszélyeztető környezeti hatásokról az iskolának kötelessége volt a gondnokságnak, illetve iskolaszéknek jelentést tenni. (31.000/1942 V.K.M. sz. r. 289.)

\section{A fegyelmezés elméleti megközelítései}

Foerster (1913) a megfélemlitéssel és az erőszakkal szemben a lelki beleegyezésre és az együttmúködésre, azaz a fegyelemnek való önkéntes alávetésre helyezte a hangsúlyt. Ezzel lehet biztosítani a fegyelmezés magtartásformáló hatását, s a rend és a szabadság, a fegyelem és az emberi méltóság összeegyeztetését. éppen ezért vetette el az iskola kényszerítéseket, melyek látszólagos, külső fegyelmet ugyan biztosítanak, ám ez az egyén becsület- és felelősségérzésre való nevelése nélkül nem vezethet a szabad polgár kialakításához. Mivel ez tanulás és gyakorlás nélkül nem alakul ki, ezért szükséges az iskola demokratizálása. Ugyan a 19-20. század fordulóján a jogkiszélesedés folyamatának lehetünk tanúi, ám ezek még nem jelentkeztek a tömegiskolákban alkalmazott fegyelmezés területén. Foerster ezzel kapcsolatban kora tanítóképzőit bírálta, melyek a gyakorlatban 
alig alkalmazható elvont ismeretek tömegével terhelte hallgatóit. Ezzel szemben a John Dewey szükségletorientált pedagógiáját emelte ki, aki könyvében az „Iskola és társadalom” -ban arra is választ keresett, hogy a szabad állam számára, hogyan lehet szabad polgárokat nevelni. Ehhez az ismeretközlésről a jellemnevelésre kell a hangsúlyt fektetni. Foerster a tekintély és a szabadság képviselói között arany középutat ajánlotta. Részben a rendnek az önkéntes engedelmességen kell alapulnia, a szabadság pedig akkor valósul meg, ha kialakítják az egyén és a társadalom összhangját. Ellenkező esetben míg a tekintély megteremtésére irányuló erőszak magának a tekintélynek árt leginkább, addig a korlátlan cselekvési szabadság magát a tekintély elvét erősítik. Az egyensúly megteremtését a korábbi, egyéniséget háttérbe szorító, s a XX. század elejének azt mindennel feljebb állónak hirdetô nevelési elvek küzdelme akadályozta. Foerster szemben állt azokkal, akik az engedelmességet, mint jellemrombolást állították be (Perkins Stetson, Ellen Key). Úgy vélte, hogy az iskola életre való felkészítő nevelő munkájában akadályozó tényező mind a játékos szellemű munka, mind a kényszerítő eszközök tömeges alkalmazása. Az egyik az önuralom és önmegtartóztatás, a másik az önállóság és felelősségérzés kialakulását gátolja. Kora iskoláinak hiányosságaként a tanulókat a követelmények teljesítésére ösztönző szellemi eszközök kismértékű alkalmazását és az öntevékenységre való szoktatás csekélységét emelte ki. Ugyanakkor a gyermek egyéni érdekeihez való alkalmazkodást a család, s nem az iskola feladatának tartotta. Az igazi szabadság elérését az egyén csak saját maga legyőzésével tudja elérni. Azaz az önfegyelmezésre nevelés a legcélszerűbb és legeredményesebb fegyelmezési eljárás.

A francia Payot (1921) a tanulói tevékenységek sikerét a mérsékelt, de állandó erőfeszítésben látta, mellyel meg lehet előzni, mind a kimerültséget, mind a fásultságot, fenntartva a munkakedvet, elkerülve a közömbösséget és a levertséget, így biztosítva folyamatosan a rendezett és elvárt magatartást.

Szelényi Ödön a nevelői tekintély és az ehhez kapcsolódó tanuló engedelmesség kialakítását tartotta a nevelési folyamat hatásának alapfeltételeinek, melyben az akarat szerepe a jellemképzés erkölcsi tartalommal való feltöltése volt. Payot-hoz hasonlóan az elkényeztetés, a korlátlan szabadság erkölcskárosító hatását emelte ki. Ugyanakkor a szeretettel párosuló tekintély nála nem csak a közvetlen akaratképzés alapjaként, hanem egyben a zsarnoki kegyetlenséggel szembeni lehetőségként is szerepelt. Ennek kialakítását részben az iskola és család által megkövetelt külső rendtôl várta. Míg az iskolai rendtartások fegyelmi szabályaiban ennek pontos megfogalmazása megtörtént, addig a gyermekeket a családban sokszor ettôl eltérô szocializációs és kulturális szint és követelmények vették körül. Az eltérő magatartási elvárások számtalan probléma forrásává váltak az iskolában, melyet részben a szabályzatokban próbáltak kezelni. Ennél nagyobb jelentőséget tulajdonított Szelényi a tevékenységek végzésére ösztönző jutalmazásnak, annak pozitív érzelmeket felkeltő hatását kiemelve. Ennél jóval gyakrabban alkalmazták az 1920-1930-as évek iskoláiban a büntetést, igaz annak javító jellegét hangsúlyozva a megtorlással, megfélemlítéssel és elriasztással szemben. Szelényi álláspontja is az volt, hogy a testi büntetést csak végső esetben szabad alkalmazni. Az előbbiekkel szemben a követendő példa adását emelte ki, összekapcsolva a tanulók önkormányzati tevékenységével, mint a közvetlen akaratnevelés leghatékonyabb módjával. Utóbbit ugyan az amerikai 'self government' mozgalmak erősítették meg, de a nevelés történetének korábbi évszázadaiban létező valóság volt. Az önkormányzatiság legnagyobb erényének a száraz erkölcsi tanok hirdetése helyett az erkölcsi elvek gyakorlati cselekedetekbe való átültetését tartotta (Szelényi, 1922).

Weszely Ödön Foerster tekintély-engedelmesség központú nézetrendszerén túl a gyermek önkéntes, meggyőződésből fakadó helyes, autonóm tevékenységének kialakítását elérendő célként határozza meg. Nem zárja ki teljesen kényszerítő eszközök nyomasztó hatásuk miatt kivételes - alkalmazását sem, ám a testi kényszer a kisgyermek kort követően nem javasolta. Veszélyüket az jelenti, hogy az akarat elnyomása nem igazi nevelés, s csak krízishelyzetet oldhat fel. A hipnózist mint a legerősebb szellemi kényszerítő eszköz orvostudományban való megjelenését követően a pedagógiában is alkalmazni akarták. Az elképzelések szerint a gyermek a hipnotikus álomban úgy 
javul meg, s alakul át, ahogy nevelője kívánja. Mivel nem mindenkit lehet hipnotizálni, s hatása sem tartós, nevelési szempontból eredménytelen. A kényszerítő eszközök sorában a legáltalánosabban alkalmazott a büntetés volt, mely egy adott cselekedet következményeként kellemetlen érzelmek okozását jelentette, melyeket a neveltek el akarnak kerülni, illetve megismétlődésüket meg akarják akadályozni. A pedagógiai büntetés célja nem a megtorlás, hanem a javítás volt. Ennek első lépcsőfoka a tanulók azon érzelmeinek jelentkezése volt, mint a félelem, a szégyen, és a becsületérzés. A büntetés javitó hatását a megbánás érzésének felkeltésétől várták. A büntetések közül a testit a családban is csak az erkölcsi belátással nem rendelkező gyermekek esetében tartotta alkalmazhatónak Weszely, ám az iskolában teljes mértékben elvetette azt részben a pedagógusok lelki eldurvulásától, önuralmának hiányától, részben a tekintélyvesztésétôl tartva. A tanítók szülőkkel és a törvényekkel való szembefordulását is kockáztatta testi fenyítést alkalmazva. Ezzel szemben a szellemi büntetések, mint a rosszallás kifejezése, a társak előtti megszégyenítés okozta érzelmek útján hatottak. Ez azonban hatása révén elkeseredést, dacot, és az önérzet csökkenését is okozhatott. Ezért minden büntetésnek a tanuló tettének megbánására kellett irányulnia (Weszely, 1932).

A büntetés sok-sok negatív hatása felvetheti a kérdést, hogy egyáltalán szükség van-e rá? Weszely válaszában célként a büntetés szükségtelenségét tûzte ki, ám nem zárta ki az azt elkerülhetetlenné tevő körülmények kialakulását. Ebből következik, hogy nem lehet ugyan a nevelő első és legfontosabb eszköze, ám nélkülözhetetlen visszatartó erejünek tartották alacsony értelmi és erkölcsi szinten állók esetében. Alkalmazása pszichológiai megérzést, megértést és tapintatot kívánt a nevelőtől, s az elkövető egyéniségének, lelkiállapotának, s a tett körülményeinek ismeretét (Weszely, 1935).

Mitrovics Gyula szerint a büntetéssel és a jutalmazással, mint fegyelmezô eszközökkel a neveltek akaratát kell befolyásolni a neveló által kitűzött célnak megfelelően. Mindehhez felügyeletet, büntetést, jutalmazást, példát és szoktatást kell alkalmazni, mint közvetlen eszközöket. Legelőször is a gyermeket mind a káros testi, mind a káros lelki hatásoktól meg kell óvni. Ez a felügye- let megköveteli a nevelő és a nevelt közös élményú aktív együttmúködését. A tanítási órákon a felügyelet fegyelmező jellege jelentkezik, a büntetésben és jutalmazásban, ám megfelelő tanítási módszerek alkalmazásával ezen fegyelmező eszközökre nincs, vagy alig van szükség. Különösen a büntetésre, mely Mitrovics szerint csak önkényes lehet a büntetés és az elkövetett hiba közötti logikai kapcsolat hiányában, s legfeljebb csak a mértéke igazodhat a nevelt hibájához, vagy mulasztásához. Bárhogy is történik, mindenféleképpen a lélekbe való drasztikus beavatkozásnak tartotta Mitrovics, mely a tanuló eldurvulásának veszélyével jár, a WeberFechner féle pszichofizikai alaptörvény által. Kikerülhetetlen büntetés esetén a legfontosabbnak az azonnaliságot, s a nevelt megszégyenítésének elkerülését tartotta, a nyilvánosság kirekesztésével. Az anyagi értékekkel való jutalmazást sem tartotta a személyiség fejlesztésére igazán alkalmas módszernek. Mitrovics meglátása szerint a munkával töltött felnőttkorban a tetteket nem minden esetben követi közvetlenül sem büntetés, sem jutalom, ezért inkább a nevelő célja az kell, hogy legyen, hogy a nevelt elvégzett munkájának az eredményét jutalomnak, s elmaradását büntetésnek érzékelje. Utóbbiak a természetes következmények elvén nyugodtak, melyeket Rousseau után Herbert Spencer támogatott, mivel ezek amellett, hogy a tettek várható következményeirôl helyes ismereteket alakítottak ki, a nevelő személyes érintettségétől voltak mentesek, így nem zavarta meg viszonyát a gyermekkel, és a szülókkel. E büntetés alkalmazhatóságának korlátait a gyermekre és környezetére veszélyes, illetve a csak hosszútávon ható - okokozati kapcsolatot vesztő - következmények jelentették. Alkalmazási lehetőségeit elsősorban az életkor, és a gyermek egyénisége befolyásolja, ám a testi büntetést minél korábban fel kell váltania a fegyelmezés enyhébb fokozatainak. A büntetések konkrét, formái közül Mitrovics a koplaltatást teljesen kizárta, mivel a gyermekek étkeztetésében bármiféle megszorításnak csak egészségügyi okai lehettek, a lemondás és önuralom értékeit erősítve. Az elzárás értelme csak az lehetett, hogy a gyermek azt érezze, hogy a zavaró körülményektól akarja a nevelő távoltartani. Az ütlegelést csak enyhe mértékben, a nevelő szánalmának és szeretetének érzékeltetése közben kora gyermekkorban vélte alkalmazhatónak. De a korholást és szidást is csak 
meggondoltan és fokozatosan alkalmazva, lekicsinyléstől és leckéztetéstől mentesen ajánlotta, kiemelve az emberi méltóság megbecsülését. Mindezekkel szemben, mint megelőzést a tanító következetességét emelte ki a tanuló kötelességteljesítésének elvárásában. Mitrovicsnál ez jelentette keménykezû szigorúságot, a büntetések és jutalmazások összhangjának biztosítását a magatartás természetes következményeiként (Mitrovics, 1933).

Bognár Cecil szerint mivel a legtöbb ember értelmi és erkölcsi szintje nem juttatja el ôt a helyes magatartáshoz és viselkedéshez, ezért szükségesek a számára kellemes, illetve kellemetlen következmények biztosítása jutalmazással és büntetéssel. Utóbbi vonatkozásában Bognár is a túlságosan kemény büntetés elkerülésére hívta fel a figyelmet (Bognár, 1940).

Várkonyi Hildebrand a család szerepét emelte ki, mint legerősebbet a szokások kialakítása terén. Fontosnak tartotta a túlzott elkényeztetés és durva bánásmód elkerülését, bár ennek nehézségét jelezte, hogy ezek részben a szülők személyiségéből, hajlamaikból, jellemükből, műveltségükből, egymáshoz való viszonyukból, életük rendezettségéből adódtak. A nem megfelelő családi környezet tényezôi közül a hiányos és hanyag nevelést és durva bánásmódot emelte ki, ezek súlyos lelki károsodást okozó következményei miatt. Mivel a nevelés egyik fontos célkitűzéseként az önuralom és a lemondás képességeinek a kialakítását határozta meg, ezért nem tartotta megfelelőnek sem a túl szigorú, sem az enyhe, sem a gyakorlatilag hatástalan fegyelmezést. A magatartás romlásában kiemelkedô szerepet tulajdonított a befolyásolható egyéniségnek, az impulzív cselekedetekre való hajlamnak, és a kortáscsoport deviáns példájának (Várkonyi, 1944).

Alfred Adler a nevelésben az individuálpszichológia alkalmazását támogatva a tanítóknak a gyermek lelkének alapos tanulmányozását javasolta ám ôk a tanítás eredményességét féltették ettől. Mivel az iskola nap mint nap találkozik iskolakerülő, késő, zárkózott, agresszív, örökmozgó tanulókkal, s nem mindenben tudja a felelősséget a szülőkre hárítani, kik pedagógiai ismeretük hiányosságai miatt vagy egyáltalán nem törődnek gyermekükkel, vagy túlságosan komolyan fogják fel a problémát. Az iskolának Adler szerint mind a gyermek, mind osztálytársai érdekében be kell avatkoznia a nevelési hibák következményeinek javítása érdekében. Ehhez szükségesnek tartotta a szülő és iskola közötti szoros kapcsolat megteremtését, hogy az így kialakított bizalmi légkörben meg lehessen győzni a szülőket nevelési módjuk változtatásáról, s arról, hogy a tanítóval való együttes nevelési módszereik sikert eredményezhetnek. Ennek eredményessége érdekében Adler Bécsben tanácsadóhelyeket szervezett nehezen nevelhető gyermekek és szüleik számára, ahol a pszichológus-idegorvos Adler, a szülők, a tanító és a gyermek külön-külön, majd együtt beszélték meg a problémát. Ezen találkozások alkalmat adtak a gyermeknevelés hibáinak okfeltárására, s a gyermek magatartása mögötti lelki problémák felismerésére, s kezelésére. Iskolai keretek között a társas érintkezés szükségességének fejlesztését, és az iskolai közösségben való lét pozitív érzésének erősítését emelte ki Adler (k.h. 1928).

\section{A fegyelmezés gyakorlata}

A Magyar Gyermektanulmányi Társaság 1918ban kérdőívet bocsátott ki a testi fenyítéssel kapcsolatos adatszerzés érdekében. A felmérés apropóját az adta, hogy a háború következményeként megnőtt a gyermekek elzüllésének veszélye, melynek kezelése során a testi fenyítés alkalmazása, mint szükségesség került elôtérbe. A válaszadók többsége szükséges nevelő eszköznek találta a büntetést, ám míg a feddést, a szabadság- az étel-és a szeretetmegvonást alkalmazását helyeselték, addig a testi fenyítés kérdésében nagy véleménykülönbségek alakultak ki. Többen a tekintély helyreállításának végső eszközét látták benne elsődlegesen erkölcsi vétségek esetén, de tanulmányi hanyagságért nem tartották megengedhetőnek. A vélemények a verést közönséges dresszúraként felfogó és azt elutasítóktól egészen a gyermek egyéniségének függvényében történő alkalmazhatóság mellett kiállókig terjedtek. Ugyanakkor voltak olyan válaszadók is akik a testi fenyítést 6-12 közötti gyermekek számára igen, azt követően az önérzetre és a jellemre való káros hatása miatt nem ajánlották. A testi fenyítés elkerülhetetlen alkal- 
mazása esetén a büntetőtől a vétség mérlegelésén túl elvárták, hogy mindeközben ne legyen indulatos, dühös, kérlelhetetlen, és durva, s a gyermekben a büntetés igazságosságának, és a büntetô szeretetének érzése alakuljon ki. Mivel a büntetés során a büntetők közül sokan haragjukról és felindulásukról számoltak be, ezért célszerúnek mutatkozott számukra a testi fenyítéstôl való tartózkodás. Az alkalmazásról alkotott eltérő véleményekkel szemben egyöntetűen érzelmi hatásaként a megfélemlítést fogalmazták meg. Ez pedig a sikeres nevelómunka eredményességéhez nélkülözhetetlen nevelt és nevelő közötti bizalmi légkör helyett a félelemét alakítja ki (Nógrády, 1933).

Márpedig az általános kép inkább elkeserítő volt. Mivel az egyéniség kialakításában az értékek átadásnak fontossága miatt szükségesnek látták az iskolákban a parancsot, a tilalmakat, az engedelmességet, a kényszerítést, a jutalmazást és a büntetést mint nevelő eszközök alkalmazását. Az iskolák házirendjében a pontosságot, a tisztaságot, a csendet, a figyelmet, a fegyelmet, a rendes viselkedést, az udvariasságot, az előzékenységet, a tisztaságot hangsúlyozták zömmel tiltások formájában. Ezáltal a mit nem lehet csinálni és nem a mit szabad tenni jutott el a tanulókhoz, megfelelő büntetőszankciókkal alátámasztva. Az ellenőrzés és büntetésközpontú iskolákban a szabályok megsértése miatt kiszabott büntetéseknek volt ugyan visszatartó erejük, ám ennek hátterében inkább a büntetéstől való félelem állt. A hibakeresés, az árulkodás, a tévedésekre való lecsapás szelleme uralkodott. A büntetések sorában gyakori volt a térdepeltetés, a sarokba állítás, a bezárás, és a szóbeli megszégyenítés, de fellehető volt még a büntetés íratás, s valamilyen megszégyenító jel viseltetése is.

Ezzel szemben az 1925-ben kiadott népiskolai tanterv a tanulók jó, és helyes cselekedeteire, és lelki értékeire építő nevelő munka fontosságát emelte ki, a büntetéssel szemben a jutalmazásra helyezve a fó hangsúlyt. Mindez hozzájárult a tanulók önbizalmának erôsödéséhez, erőfeszítésük és teljesítményük fokozásához. Ez nem csak a tehetséges és jó tanulókra, hanem a gyengébbekre is igaz volt. A helyes cselekedetek észrevétele, elismerése és jutalmazása során keletkezett pozitív érzelmek lelki felhajtó ereje újabb sikerek elérésére inspiráltak. Utóbbi azonban önhittséget, hiúságot és irigységet is okozhatott. Egyfajta veszélyként jelentkezett a jutalom reményében végzett cselekedet, hiszen erkölcsi értéket csak annak a tevékenységnek tulajdonítottak, melyet önmagáért a jó cselekedetért végeztek. Fontosnak tartották, hogy a jutalmazás területén a tanító mellett az osztálytársak is kapjanak erre lehetôséget. Mindezt abból kiindulva, hogy az iskolának a gyermekben levő jóra kell koncentrálnia, azt fejlesztve tovább. Ezt a folyamatot a népiskola a szereteten alapuló játékos késztetéssel alapozta meg. A büntetés elhagyását azonban az alacsonyabb értelmi és erkölcsi fokon lehetetlennek tartották, azonban csak, mint utolsó eszközt. Ehelyett a helytelen cselekedetek negatív erkölcsi tartalmának a beláttatása, elkerülési és jóvátételi lehetőségének megismertetése volt a tanító feladata. A büntetés, mint egyfajta elégtétel, mely által megtörténik a bocsánat elnyerése (Drozdy,1936). Arra a kérdésre, hogy kit is tekintettek nehezen nevelhető gyermeknek a korszak népiskoláiban, egyszerú választ adhatunk. Mindenkit ide soroltak, kikre nem hatottak a tanulók zöménél eredményre vezető nevelési és oktatási eljárások és módszerek. Ennek háttere összetett volt, így mind a feltárás, mind a javitás nehézségekbe ütközött. Ide tartoztak a pszichés tényezők, mint az öröklött hajlamok és gátlások, a szociális tényezők, mint a szülői ház és a lakókörnyezet gyermeket veszélyeztetői hatásai, a gyermek lelki adottságainak megnyilvánulásai. Ide sorolták a nyugtalanságot, az összeférhetetlenséget, az akaratosságot, az alattomosságot, a hazudozást, a fantáziálást, a csalást, a lopást, az akaratgyengeséget, és a gyenge ítélőképességet, mint a cselekedetet irányító-meghatározó tényezőket. A problémák sokrétúsége a nevelési tanácsadók rendszerének szélesítését követelte, ahol orvosok, pszichológusok, az érintett gyermek tanítója, s iskolájának iskolanôvére adhatott volna komplex egyénre szabott megoldást nevelőotthoni elhelyezést biztosítva számukra. Mivel a probléma hátterében sok esetben a családi körülmények álltak, a gyermek védelme érdekében a válásra vonatkozó törvények szigorítását találták az egyik megoldásnak, mivel a szülók válása nagyban hozzájárult a nehezen nevelhetôség kialakulásához. Ezeken túl úgy vélték, hogy a nehezen nevelhető gyermekek számbeli növekedéséhez a népiskola 
nem megfelelő jellemnevelése is hozzájárult, melyet többen a népiskolai rendtartás és fegyelem elavultságával magyarázott, hathatós megtorló eszközt követelve a tanítóknak. A szociális reformok sürgős szükségességét a meglévő gyermekbűnözés követelte. Mivel ennek alapoka nagyrészt a nyomor volt, ennek felszámolásáért az egyénen túl a társadalmat is felelősség terhelte. A gyermekbűnözés egyik megelőzésének a tanulási idôben az iskolában való tartózkodás szigorú ellenőrzésével a csavargás lehetetlenné tétele mellett a gyermekek utcai ellenőrzésének megszervezését tartották gyermekrendőrség által. Ezeken túl a gyermekek szüleinek felelősségre vonását is nélkülözhetetlennek tartották. Igaz ugyan, hogy a gyermekbűnözéssel kapcsolatban nőtt a büntetőeljárások száma, de ennek ellenére mind a gyermekbűnözés, mind a nehezen nevelhető gyermekek száma növekedett. Mivel a kizárólagos büntetés és retorzió megfélemlítő hatása csak rövidtávon hatott, távlati javításra alkalmatlan volt. Ugyanis a társadalom alsó rétegeiből származó bűnelkövető gyermekek rendezett, jobb körülmények közé kerültek otthonukhoz képest, megfelelő étkezést, lakóteret kapva. Távlati pozitív hatást a nevelés megelőző hatásától várták. Ebben fontos szerepet játszott a nem megfelelő környezetből való kiemelés, melyre a nevelési tanácsadó pszichológiai vizsgálatát követően kerülhetett sor, átmeneti gyermekotthonban helyezve el. Erre a célra a 12 éves kor alattiak számára kifejezetten megelőző, zárt nevelőotthonok, míg a már javítónevelésre ítélteknek külön nevelőotthonok felállítását szükségeltették. Elkerülendőnek tartották az iskolaköteles korú nehezen nevelhetó gyermekek javítóintézetbe kerülését.

A megelőzést szolgálandóan a napközi otthonok átfogó reformja mellett, és a tankötelezettségi törvény szigorú végrehajtását emelték ki. Utóbbihoz kapcsolódóan a Budapesti Tanítótestület 1937-ben a népiskolai fegyelem és rendtartás korszerúsítését javasolta a VKM miniszternek. Ebben a fegyelmi büntetések minimalizálásának igényével léptek fel az osztály előtti intésre, az igazgató dorgálására, a tanítótestület előtti intésre, a szülők értesítésére és közremúködésére, valamint a házi fegyelmezés alkalmazására, és a hatóság intézkedésére redukálva aztokat. Szükségesnek látták, hogy a tanító is rendelkezzék, - mint aki a szülőt helyettesíti - a házi fegyelmezési jog gyakorlásával, így a testi fenyítést alkalmazhassák mind a fegyelmezetlen, mind a durva, mind az erkölcsi züllésnek indult tanulókkal szemben. Ezek mellett akár a szülók akarata ellenére, jogkörük csökkentésével, fontosnak tartották a nehezen fegyelmezhető, és züllésre hajlamos gyermekek átmeneti elhelyezését más iskolába. A magatartásból adható osztályzatok megváltoztatásának és bővítésének lehetôségével az iskola visszajelzésének súlyát akarták emelni. Preventív jelleggel az erkölcsi jellemképzés céljára nevelési óra beállitását javasolták, mégpedig a harmadik testnevelő óra helyett. A tanító egyfajta függetlenségének biztosítását kívánták elérni azzal, hogy nevelő-oktató munkájáért csak a tanügyi hatóságnak legyenek felelősek. Ezzel a különböző társadalmi viszonyok között múködő iskolákkal szembeni egységes elvárások teljesítésének biztosítását várták (Tóth, 1942).

A testi fenyítéssel kapcsolatosan láthatjuk, hogy az elmélet és a gyakorlat egészen távol járt egymástól. Míg az elmélet egyértelmúen elvetette, addig a gyakorlati alkalmazása mindennapos volt. Céljának megítélésében is kettőséget láthatunk. Egyik oldalról a javítás, másikról a megfélemlítés és elrettentés, harmadikról a megtorlás dominált. Javitó hatását megkérdőjelezte a megbüntetettek ismételt hibaelkövetésének megismétlődése, s a megbánás érzésének felkeltésének hiánya. A büntetés elrettentő hatása ugyan részben visszatartó erôvel bírt, ám a rossz cselekedetektől való tartózkodás még nem jelentette azt, hogy ezt megbánva, megjavult, csak azt, hogy a rossz cselekedetért büntetést kap. A büntetést megtorlásként értelmezők az erkölcsi rend helyreállítását tartották szem előtt, mely alapvetően jogi nézőpontot jelentett, ám nevelési szempontból azért volt értéktelen, mivel a megbüntetett igazságtalannak, illetve bosszú következményének tarthatta, ezért a neveló javító célját nem érhette el. A nevelés javító jellege nem a minden hiba megtorlásában volt, hanem a tett elkövetőjének megbánásának, lelki tisztulásának elérésében.

A büntetéssel kapcsolatban ugyan már azt is eredménynek tartották, ha visszatartó ereje folytán a rosszra való hajlam megléte esetén sem történt rossz cselekedet, ám ez is súlyos károkat okozott a gyermek lelki fejlődésének akadályozásával. Ezt csak fokozta a megszégyenítés, a megalázás, az 
önérzet és a munka- és életkedv csökkenése. A kishitûvé vált gyermekben ez elkeseredést, gyúlöletet, dacot és makacsságot válthatott ki a büntetôvel szemben. Ez a szemlélet, ha lassan is kezdett megjelenni a nevelői gyakorlatban. A testi büntetést annak ellenzői, mint az állatidomítás eszközét a legalsóbbrendú büntetésnek tartották, mely a gyermeket mélyen megalázza és megszégyeníti ôt, s már a 6 éven aluliaknál sem múködik sikeresen, a serdülőknél pedig inkább az ellenszegülést növeli, a lányoknál fokozottabban. Ezt erôsítette az a tény, hogy a büntetésekben nagyrészt a felnőttek hangulata, indulata, önuralmának elvesztése játszotta a fő szerepet, s az elhamarkodottan, a mérlegelés hiányában hozott igazságtalan döntések következményeit, nehezen tudták elviselni a gyermekek. Különösen azért, mert sok esetben a tanítói tehetetlenségből fakadva minden nevelói gondolat híján volt. Ennek részben a vélt, vagy valós tekintélysérelem volt az oka. Mivel az iskola feladatának a gyermek nevelését és nem a hozzá való alkalmazkodást tartották, ezért a tanulóknak az iskola színvonalához való felemelését javallották, mely folyamatban a büntetést inkább a gyermek lelki életébe történő drasztikus, eldurvulást okozó beavatkozásnak látták (Somody,1941).

\section{Jogi háttér}

A dualista Magyarország jogi rendszerének kiépülése során a testi fenyítéssel kapcsolatos intézkedések sorozatában az 1876: XIII. tc.-ben került sor a cselédek és gazdáik közötti viszony szabályozásáról, melyben a gazda jogot kapott a 46. §-ban nem csak a dorgáláshoz, hanem a fizetésmegvonáson túl a fenyítésre is. Igaz a 47. § alapján a fenyítettnek jogában állott hatósághoz fordulni, amennyiben igazságtalannak érezte a büntetést.(1876.XIII.tc.)

Az 1877. XX.tc. 10. §-ában engedélyezték a kiskorú egészségére nem ártalmas házi fegyelmet, ennek megfelelően a testi fenyítést (1877: XX. tc.).

A korszak büntetőtörvénykönyve, az 1878: V. tc. 301. §-a a testi sértést a más testének szándékos, ölési szándék nélküli bántalmazásaként határozta meg, és elnevezését az okozott sérülés gyógyulásának hosszától függően a könnyú testi sértés vétsége és a súlyos testi sértés bủntette között határozta meg, s büntetési tétele a $302 . \S$ meghatározása szerint hat hónapig terjedhető fogháztól és kétszáz forintig terjedhetô pénzbüntetéstől a 3 évig terjedhető börtön volt, ugyanakkor ha ezt szülőkkel, nagyszülőkkel, dédszülőkkel szemben követték el a büntetési tételek 2 -5 évre emelkedtek. Amennyiben a testi sértés maradandó egészségi akár fizikai, akár szellemi- károsodást okozott a 303. § szerint 5 évig terjedhető börtönnel lehetett büntetni, de a szülőkkel, nagyszülőkkel, dédszülőkkel szembeni elkövetés esetén ez időt fegyházban kellett letölteni. Gondatlansággal okozott súlyos testi sértés büntetési tétele három hónapig terjedhető fogház, és kétszáz forintig terjedhető pénzbüntetés volt a 310 . § szerint. Ugyanakkor, ha a súlyos testi sértés az okozó saját hivatásában vagy foglalkozásában való járatlansága, hanyagsága miatt, az érvényes szabályok megszegve történt,- ebbe a kategóriába tartoztak a közalkalmazottak, így a tanítók és tanárok is - már egy évre terjedhető fogház és ötszáz forintig terjedhetô pénzbüntetésre emelkedett a büntetési tétel. A 311. § alapján kártérítés megállapítására is sor kerülhetett. Mivel az iskolákban alkalmazott testi fenyítések zöme a könnyú testi sértés vétségének kategóriájába esett, mely esetében bűnvádi eljárás csak a sértett fél indítványára volt megindítható a 312. § szerint, a családokban általánosan alkalmazott testi büntetések korszakában - a 313. § a könnyủ testi sértés esetében kizárta a büntetést - erre ritkán került sor. (1878: V.tc.)

A gazda és a gazdasági cseléd közötti jogviszonyt ismételten meghatározó 1907: XLV.tc. 46. §-ában a cselédek - a házi fegyelem alatt nem állók is - már jogot kaptak arra, hogy elhagyhassák szolgálatukat felmondás nélkül, ha testi épségüket, életüket veszélyezteti a gazda (1907: XLV. tc.).

Az 1908: XXXVI. tc., a Büntetőnovella II. fejezete 15. §-a megfogalmazása szerint „Az ellen, aki a bủntett vagy vétség elkövetésekor életének tizenkettedik évét meg nem haladta (gyermek), sem vád nem emelhetô, sem búnvádi eljárás nem indítható. Ha a gyermek bűntettet vagy vétséget követett el, a hatóság, amely elé kerül, őt megfenyítés végett a házi fegyelem gyakorlására jogosított egyénnek vagy az iskolai hatóságnak adhatja át. Az iskolai hatóság a gyermeket megdorgálhatja vagy 
iskolai elzárással fenyítheti." E törvény 16. §-a megfogalmazása szerint „Az, aki a bűntett vagy vétség elkövetésekor életének tizenkettedik évét már meghaladta, de tizennyolcadik évét még be nem töltötte (fiatalkorú), ha a büntethetôséghez szükséges értelmi és erkölcsi fejlettségre nem volt meg, büntetőjogi felelősségre nem vonható. Ha a bíróság ily esetben szükségesnek látja, elrendelheti, hogy a fiatalkorút törvényes képviselője, hozzátartozója vagy más alkalmas egyén házi felügyelet alatt tartsa vagy intézkedhetik az iránt, hogy a fiatalkorú házi vagy iskolai fenyitést kapjon (15. §. második bekezdése).” (1908: XXXVIII.tc.)

Mivel a törvény alapján az iskola is feladatot kapott a büntetési tevékenységben érhetô, hogy ezzel kapcsolatban az illetékes tárcának, a vallás-és közoktatásügyi minisztériumnak is intézkednie kellet a végrehajtás vonatkozásában.

A 149.500/1909. V. K. számú rendeletben szóltak legelőször széles körben az iskolákra háruló feladatokról, ennek érvényességi köre kiterjedt az állami, községi, egyesületi (társulati), magán és izraelita hitfelekezeti elemi-, felső-, nép-, polgári-, iparos-és kereskedő-tanonciskolákra, tehát felölelte a népoktatási intézményeket. A családokkal kapcsolatban külön kezelték azon szülőkkel való foglalkozást, akik önhibájukon kívül (betegség, munkanélküliség) átmenetileg anyagi okokból nem tudták gyermekük számára biztosítani a megfelelő erkölcsi nevelést, azoktól a szülóktől akik állandó anyagi zavarokkal küszködtek tartós betegségük, alkoholizmusuk miatt, illetve elhagyták gyermeküket. Külön kategóriát képviseltek a gyermeküket szándékosan veszélyeztető, elhanyagoló, illetve velük szemben bűncselekményt elkövető szülők.

Míg az első esetben a tanítóság feladata a családok helyzetén segíteni tudó jótékonysági egyesületek irányába történő jelzés volt, addig a másik két esetben a családi háttér pontos megismerését követően az iskolai gondnoksághoz kellett fordulnia, jelentési kötelezettséggel.

Mivel a bíróság elrendelhette a már jelzett 15-16.

$\S$-okban a szülő, illetve az iskolai hatóság által történő fenyítést is, ezért az iskolának környezettanulmányt kellett a bíróság számára készíteni. „Az iskolai fenyíték nemei a következők:
1. Szóbeli megdorgálás magánosan (négyszemközt).

2. Szóbeli megdorgálás, a tanítótestület, a gondnokság, az iskolaszék, vagy az ipariskolai bizottság elôttt.

3. Iskolai elzárás éheztetés nélkül.

4. Iskolai elzárás éheztetéssel."

A dorgálással kapcsolatosan a komolyságra, és a jóindulatra hívták fel a tanítók figyelmét. Ezzel kapcsolatban rámutattak arra, hogy a büntetés elfogadásához, és annak pozitív hatásához nélkülözhetetlen a gyermek és tanító közötti bizalom megléte. Ugyanis csak ebben az esetben volt lehetőség arra, hogy a tanító által feltárt rossz szokások, jellemhibák, erkölcsi normaproblémák negatív következményeit a gyermek is belássa, s elfogadja azokat a tanácsokat, melyek helyes magatartásához vezethetnek. Éppen ezért kizártnak tartották nemcsak a testi fenyítést, de a nyilvános megszégyenítést is. Így a büntetés egyéni jellege miatt az osztály-és iskolatársak tudomására jutás is kerülendő volt, s nem szerepelhetett a tanuló bizonyítványában sem. (MRT, 1909.)

Az 1884-es ipartörvény 1922-es módosítása alapján a tanoncot munkaadója megfeddhette, megdorgálhatta nemét, korát figyelembe véve, s tisztességében, önérzetében nem sértve őt. Az 1922: XII. tc. 95. §-a szerint 16 év alatti fiúk vonatkozásában az enyhe testi fenyítés megengedhetô volt, ám ellátásban nem szenvedhetett hátrányt. (1922: XII.tc.)

\section{A tanítóság}

A tanítóság fegyelmezési jogkörével kapcsolatosan a népiskolai hatóságokról rendelkező 1876: XXVIII.tc. 7. §. 3. pontja szerint a növendékekkel szembeni durva bánásmód hivatali vétségnek számított, s az ellene folytatott fegyelmi vizsgálat alatt felfüggesztésre kerülhetett, s az ellen hozott büntetések a 4. pont alapján lehetett megintés, vagy dorgálás, pénzbírság, fizetésének $10 \%$-áig, nyugdíigényének elvesztése, s állásából való elbocsájtás elrendelése. A vizsgálatot a szolgabíró, a bíró, illetve a polgármester rendelhette el az iskolaszék, vagy a gondnokság meghallgatása mellett. A tanfelügyelő, illetve megbízottja is jelen lehetett a vizsgálatnál, melynek befejeztével a fegyelmi bírás- 
kodást a közigazgatási bizottság fegyelmi választmánya gyakorolta, s a döntést a VKM-hez juttatta el. A döntés ellen a közigazgatási bizottság elnökénél fellebbezéssel élhetett az érintett. A nyugdíjjal, és az állással kapcsolatos büntetések a VKM hatáskörébe tartoztak. E törvény 3.4. pontjában megfogalmazottak nem terjedtek ki az állami tanító-és tanítónőképző intézetekre és azok gyakorló iskoláira (1876: XXVIII.t.c).

Ezen törvény 3.4. pontjait 1907-ben módosították a XXVI.tc. 14. §. 1-4. pontjában. Az állami elemi népiskolai tanítóknak a növendékkel szembeni durva bánásmódja már nem hivatali, hanem fegyelmi vétségnek számított, s ellene a gondnokság, vagy valamely tagja, illetve a tanuló törvényes gondviselője is feljelentéssel élhetett, melyet a közigazgatási bizottságnak kellett kivizsgálnia. De saját jogkörben, illetve a VKM elrendelésére is elindíthatták a vizsgálatot. A fegyelmi eljárás során az érintett tanítót állásából felfüggeszthették, mely büntető bírósági ügy esetén kötelező volt. A vizsgálatot végzók köre megegyezett az 1876-os törvényben megfogalmazottakkal, viszont a tanító ügyvédi védelmet is igénybe vehetett. A bíráskodási jogkörrel rendelkezők szintén megegyeztek az 1876-ban leírtakkal. Ugyanakkor a fegyelmi választmány tagja, aki a tanító ellen tette a panaszt, vagy a vádat emelte nem vehetett részt sem a tanácskozásban, sem a ítélethozatalban. A döntés után az érintett tanítónak az 1876-os 8 nap helyett jelen törvény alapján 15 nap állt rendelkezésére a VKM miniszterhez való fellebbezésre. Ez utóbbit továbbra is a közigazgatási bizottság elnökéhez kellett benyújtani. A fegyelmi büntetések is módosultak 1876-hoz képest. Míg a dorgálás megmaradt, addig a nyugdijigény elvesztésével való büntetés kikerült. A büntetés enyhülését jelentette az állásából való elbocsátást felváltó a saját költségen, más állomáshelyre való áthelyezés. A 10\%-os pénzbírság továbbra is fennmaradt, újként jelentkezett a fizetésemelésből való meghatározott időre szóló kizárás, mely maximum 2 évre terjedhetett ki. Ennek súlyát az emelte, hogy a kiesés nem számított be a fizetésemelés szempontjából irányadó szolgálati évekbe. Utóbbi büntetést az áthelyezéssel történővel együtt is alkalmazták (1907: XXVI.tc.).
A községi és hitfelekezeti néptanítók vonatkozásában intézkedő 1907: XXVII. tc. 22. §-a 1-4 pontja az 1876: XXVIII.tc. 7. §-ának 3-4. pontját módosította. A fegyelmi vétségek sorában a növendékkel való durva bánásmód továbbra is szerepelt. Az intézkedő hatóságok és az intézkedés folyamata megegyezett az állami néptanítóknál leírtakkal. A büntetési tételek sorában a községieknél továbbra is szerepelt az állásából való elmozdítás lehetősége, illetve itt a korpótlék maximum két évre való megvonás szerepelt az államiak fizetésemelésből való kimaradása helyett (1907: XXVII.tc.). Mivel a tanítókat a házi fegyelmi jog gyakorlására nem jogosította törvény, így a testi sértéshez kapcsolódó büntetési tételek rájuk is vonatkoztak. Ez utóbbit erōsítette a Kúria 211/1908 számú jogegységi határozata, mely szerint a tanítók növendékeikkel szembeni fegyelmi jogköre nem terjedt ki a testi fenyítésre. Ugyanakkor már Horthy-korszakban a Kúria 5991/1928. számú jogegységi határozata feljogosította a tanítókat bizonyos esetekben a házi fegyelmi jog gyakorlására. A magyar bírósági gyakorlatban ugyan nem alakult ki olyan gyakorlat, mely a tanító által alkalmazott testi fenyítésért büntetőjogi felelősség terhelte volna, ám az érvényes törvények alapján testi sértés okozása esetén már igen (Somodi,1941).

\section{Kitekintés}

1930-ban hivatkoztak a New Education Fellowship The New Era folyóiratára, mely az iskolai testi fenyitéssel foglalkozott. Ezek szerint Egyiptomban ennek tilalmát 1891-ben rendelték el, míg Argentínában 1860-ban törvény tiltotta meg alkalmazását. Ausztráliában ugyan törvény engedélyezte a 12 éven aluli lányok kivételével, de csak súlyos erkölcsi vétségek, és visszatérô engedetlenség esetén. Belgiumban ugyan tiltották a verést, ám a szülői tiltakozások ellenére gyakran előfordult. Brazíliában állami rendelet tiltotta az iskolai testi fenyítést. Bulgáriában is törvény tiltotta, de enyhébb formában alkalmazták. Kanadában megengedett volt, ám fokozatosan a felszámolásához közeledtek. Ceylonban a rossz magaviselet és hanyagság esetén megengedett volt, de a lányokat csak tantónő fenyíthette. Chilében és Dániában korlátozottan ugyan de engedélyezett volt a testi 
fenyítés. Angliában a nyilvános iskolákban más fegyelmezési módok eredménytelensége esetén használhatták. Sajátos volt, hogy csak az igazgató gyakorolhatta, hasonlóan Indiához és Írországhoz. Angliában elvetették a bottal, és a bőrszijjjal történő büntetést, s a fiúiskolákban volt jellemző, ott is növekvő ellenzés mellett. Írországban az iskolai előmenetel nem megfelelősége esetén nem lehetett büntetni. Görögországban, Észtországban, Olaszországban, Japánban, Jugoszláviában, Mexikóban, Norvégiában, Hollandiában, Peruban, Lengyelországban, Portugáliában, Romániában, Törökországban, Csehszlovákiában egyaránt tilos volt a testi fenyítés, igaz a tilalom ellenére több országban továbbra is alkalmazták, melyek sorába tartozott Japán, Mexikó, Norvégia, Peru, Lengyelország, Portugália, Románia. Ezekkel szemben Franciaországban a közvélemény tiltakozása ellenére sem szűnt meg, s az 1899. évi törvény szerint csak hivatásos nevelők gyakorolhatták. Ugyanakkor törvényadta lehetőséget biztosított több állam is az alkalmazására, mint Újfunland, Újzélend, Ausztria, Skócia, Spanyolország, Svédország, Tasmánia, az USA 17 állama, Németország. Igaz Újzélandon csak a lányok bőrszijjal büntetését engedélyezték, Ausztriában a 11 éves, Svédországban a 14 éves kor alattiakkal szemben lehetett alkalmazni, Skóciában bottal és bőrszíjjal már kis vétséget is megtoroltak a szülók támogatása mellett. Spanyolországban a tanítók csak kivételes esetekben gyakorolták a fenyítés ezen formáját. Tasmániában mint végső eszközt alkalmazták, a 12 éven felüli lányok kivételével. Magyarországon ugyan nem volt törvényi tiltás alatt, mégis jogszabályok egész sorába ütközött alkalmazása (k.h. 1930.)

\section{Epilógus}

2016-ban a Föld 69 országban volt jogszerű az iskolai testi büntetés.

Afrika (29): Angola, Botswana, Burkina Faso, Comore szigetek, Egyenlítői Guinea, Egyiptom, Elefántcsontpart, Eritrea, Gambia, Ghána, Guinea, Közép Afrikai Köztársaság, Lesotho, Libéria, Maldív szigetek, Marokkó, Mauritánia Mozambik, Niger, Nigéria, Nyugat Szahara, Seychelle szigetek, Szenegál, Sierra Leone, Szomália, Szudán, Szváziföld, Tanzánia, Zimbabwe.
Ázsia (21): Bhután, Brunei, India, Indonézia, Irán, Irak, Katar, Kelet-timori Demokratikus Köztársaság, Koreai Köztársaság, Koreai Népi Demokratikus Köztársaság, Libanon, Malajzia, Mianmar, Nepál, Pakisztán, Palesztin Állam, Pápua Új Guinea, Sri Lanka, Szaúd Arábia, Szingapúr, Szíria

Amerika (14): Antigua és Barbuda, Bahama szigetek, Barbados, Dominika, Grenada, Guatemala, Guyana, Jamaica, Panama, St Kitts és Nevis, St Lucia, St Vincent és a Grenadine szigetek, Suriname, USA

Ausztrália és Óceánia (4): Ausztrália, Palau, Szamoa, Salamon szigetek, Tuvalu

Európa (0). (Gershoff, 2017.)

\section{Irodalom}

Foerster Friedrich Wilhelm (1913). Iskola és jellem. Adalékok az engedelmesség neveléstanához és az iskolai fegyelem átalakitásához. németböl. Lampel $\mathrm{R}$. Könyvkereskedése Wodianer F. és fiai Részvénytársaság, Budapest.

Mitrovics Gyula (1933). Neveléstudomány alapvonalai.

Debrecen-Budapest. Csáthy Ferenc R.T. Egyetemi Könyvkereskedés. Kertész József Könyvnyomdája. Karcag.

Payot Jules (1921). Az akarat nevelése. Franklin Társulat, Budapest.

Szelényi Ödön (1922). A neveléstan alapvonalai. Genius Könyvkiadó R.T. Budapest., „Jókai” Nyomda R.T. Budapest.

Várkonyi Hildebrand (1944). A gyermek és környezete. Szinyei Merse Jenő a M. Kir. Vallás- és Közoktatásügyi Miniszter megbízásából kiadja Az Országos Közoktatási Tanács. Budapest.

Weszely Ödön (1932). Pedagógia a neveléstudomány rendszere rövid összefoglalásban. Révai Kiadás, Budapest.

Weszely Ödön(1935). A korszerü nevelés alapelvei, a neveléstudomány rendszere. Királyi Magyar Egyetemi Nyomda, Budapest

Lexikonok

KL (Katolikus lexikon) Szerkesztette: Bangha Béla. II. Kötet Budapest, 1931. A Magyar Kultúra Kiadása 
RNL (Révay Nagy Lexikona) VII. kötet Budapest.1913. Révai Testvérek Irodalmi Intézet Részvénytársaság

PL (Pedagógiai Lexikon) I. rész Szerkesztette: Fináczy Ernő, Kornis Gyula, Kemény Ferenc. Révai Irodalmi Intézet Kiadása. 1936.

Folyóiratok

Bognár Cecil (1940). A jutalmazás és büntetés lélektana. Magyar Paedagogia XLIX. évf.,1516.

Drozdy Gyula (1936). A jutalmazás és büntetés szerepe a mai iskolai nevelésben. Néptanitók Lapja 69. (23.)

Gershoff Elizabeth T. (2017). School Corporal Punishment in Global Perspective: Prevalence, Outcomes, and Efforts at Intervention (Letöltés: 2019 01.03.) Web: https://www.ncbi.nlm.nih.gov/pmc/articles/P MC5560991/

k.h.(1928). Nevelési hibákban szenvedő gyermekek. Néptanitók Lapja,61.(9-10.)

k.h.(1930). Testi fenyíték a külföldi iskolákban. Néptanitók Lapja.63. (15-16.)

Nógrády László (1933). Büntetés a nevelésben. Néptanitók Lapja 66. (5.)

Somodi József (1941). A testi fenyítés. Néptanitók Lapja, 74. (4.)

Tóth István (1941). A nehezen nevelhető gyermek. Néptanitók Lapja, 75. (6.)

Törvények, rendeletek

Az 1876. évi XIII. törvénycikk a cseléd és gazda közötti viszony szabályozásáról, a gazdasági munkásokról és a napszámosokról. (Letöltés: 2019.01.07.)

https:/ / net.jogtar.hu/ezer-ev-

torveny?docid $=87600013$.TV\&searchUrl=/ezerev-torvenyei\%3Fkeyword\%3D1876.XIII.

$\mathrm{Az}$ 1876. évi XXVIII. törvénycikk a népiskolai hatóságokról· (Letöltés: 2019.01.07.)

https:/ / net.jogtar.hu/ezer-ev-

torveny?docid $=87600028$. TV\&searchUrl=/ezerev-

torvenyei $\% 3$ Fextraparams $\% 3 \mathrm{D} \% 7 \mathrm{~B} \% 2522 \mathrm{ID} \% 25$
$22 \% 3 \mathrm{~A} \% 2522 \mathrm{FullTextSearch} \% 2522 \% 2 \mathrm{C} \% 2522 \mathrm{Ye}$ ar $\% 2522 \% 3 \mathrm{~A} \% 25221876 \% 2522 \% 2 \mathrm{C} \% 2522 \mathrm{Kiboc}$ sato $\% 2522 \% 3 \mathrm{~A} \% 2522 \mathrm{TV} 0 \% 2522 \% 7 \mathrm{D}$

Az 1877. évi XX. törvénycikk a gyámsági és gondnoksági ügyek rendezéséről. (Letöltés: 2019.01.07.) https:// net.jogtar.hu/ezer-evtorveny?docid $=87700020$. TV\&searchUrl=/ezer-evtorvenyei\%3Fkeyword\%3D1877.xx.

Az 1878. évi V. törvénycikk a magyar büntetőtörvénykönyv a büntettekről és vétségekről. (Letöltés: 2019.02.08.)

https:// net.jogtar.hu/ezer-ev-

torveny?docid=87800005.TV\&searchUrl=/ezer-evtorvenyei $\% 3$ Fextraparams $\% 3 \mathrm{D} \% 7 \mathrm{~B} \% 2522 \mathrm{ID} \% 2522$ $\% 3 \mathrm{~A} \% 2522$ FullTextSearch $\% 2522 \% 2 \mathrm{C} \% 2522$ Year $\%$ $2522 \% 3 \mathrm{~A} \% 25221878 \% 2522 \% 2 \mathrm{C} \% 2522$ Kibocsato $\%$ $2522 \% 3 \mathrm{~A} \% 2522 \mathrm{TV} 0 \% 2522 \% 7 \mathrm{D}$

Az 1907. évi XLV. törvénycikk a gazda és a gazdasági cseléd közötti jogviszony szabályozásáról (Letöltés: 2019.02.08.)

https:// net.jogtar.hu/ezer-evtorveny?docid $=90700045 . T V \&$ searchUrl=/ezer-evtorvenyei $\% 3$ Fkeyword\%3D1907

Az 1907. évi XXVI. törvénycikk az állami elemi népiskolai tanítók illetményeinek szabályozásáról és az állami népiskolák helyi felügyeletéről (Letöltés: 2019.02.08.)

https:/ / net.jogtar.hu/ezer-evtorveny?docid=90700026.TV\&searchUrl=/ezerev-

torvenyei $\% 3$ Fextraparams $\% 3 \mathrm{D} \% 7 \mathrm{~B} \% 2522 \mathrm{ID} \% 25$ $22 \% 3 \mathrm{~A} \% 2522$ FullTextSearch $\% 2522 \% 2 \mathrm{C} \% 2522 \mathrm{Ye}$ ar $\% 2522 \% 3 \mathrm{~A} \% 25221907 \% 2522 \% 2 \mathrm{C} \% 2522 \mathrm{Kiboc}$ sato $\% 2522 \% 3 \mathrm{~A} \% 2522 \mathrm{TV} 0 \% 2522 \% 7 \mathrm{D}$

Az 1907. évi XXVII. törvénycikk a nem állami elemi népiskolák jogviszonyairól és a községi és hitfelekezeti néptanitók járandóságairól (Letöltés: 2019.02.06.) https://net.jogtar.hu/ezer-evtorveny?docid $=90700027$. TV\&searchUrl=/ezerev-

torvenyei $\% 3$ Fextraparams $\% 3 \mathrm{D} \% 7 \mathrm{~B} \% 2522 \mathrm{ID} \% 25$ $22 \% 3 \mathrm{~A} \% 2522$ FullTextSearch $\% 2522 \% 2 \mathrm{C} \% 2522 \mathrm{Ye}$ ar $\% 2522 \% 3 \mathrm{~A} \% 25221907 \% 2522 \% 2 \mathrm{C} \% 2522$ Kiboc sato $\% 2522 \% 3 \mathrm{~A} \% 2522 \mathrm{TV} 0 \% 2522 \% 7 \mathrm{D}$ 
Az 1908. évi XXXVI. törvénycikk. a büntetőtörvénykönyvek és a bűnvádi perrendtartás kiegészitéséről és módosításáról.(Letöltés: 2019.02.06) https:// net.jogtar.hu/ezer-evtorveny?docid $=90800036$. $T$ V\&searchUrl=/ezer-evtorvenyei $\% 3$ Fextraparams $\% 3 \mathrm{D} \% 7 \mathrm{~B} \% 2522 \mathrm{ID} \% 2522$ $\% 3 \mathrm{~A} \% 2522$ FullTextSearch $\% 2522 \% 2 \mathrm{C} \% 2522$ Year $\%$ $2522 \% 3 \mathrm{~A} \% 25221908 \% 2522 \% 2 \mathrm{C} \% 2522$ Kibocsato $\%$ 2522\%3A\%2522TV0\%2522\%7D\#lbj0id6e6

Az 1922. évi XII. törvénycikk az 1884. évi XVII. törvénycikkbe iktatott ipartörvény módosításáról. (Letöltés: 2019.02.04)

https://net.jogtar.hu/ezer-evtorveny?docid $=92200012$. TV\&searchUrl=/ezerev-

torvenyei $\% 3$ Fextraparams $\% 3 \mathrm{D} \% 7 \mathrm{~B} \% 2522 \mathrm{ID} \% 25$ $22 \% 3 \mathrm{~A} \% 2522$ FullTextSearch $\% 2522 \% 2 \mathrm{C} \% 2522 \mathrm{Ye}$ ar\% $\% 2522 \% 3 \mathrm{~A} \% 25221922 \% 2522 \% 2 \mathrm{C} \% 2522$ Kiboc sato $\% 2522 \% 3 \mathrm{~A} \% 2522 \mathrm{TV} 0 \% 2522 \% 7 \mathrm{D}$
MRT (Magyarországi Rendeletek Tára) Negyvenharmadik Folyam. 1909. Kiadja A Magyar Királyi Belügyminisztérium. (Az »Országos Törvénytár« szerkesztősége) Budapest, 1909, Nyomatott A »Pesti Könyvnyomda-Részvzénytársaságnál. 133. A m. kir. vallás és közoktatásügyi miniszternek 1909. évi 53.000. sz. a. kelt rendelete az állami elemi népiskolák gondnoksága és az állami elemi népiskolai tanítók és igazgató-tanítók utasításának kibocsátásáról. 1. Valamennyi kir. tanfelügyelőségnek és tanfelügyelőségi kirendeltségnek. 2. A fiumei kormányzónak. https://library.hungaricana.hu/hu/view/OGYK_ RT_1909/?pg=0\&layout $=\mathrm{s}$ 